\title{
The European Monetary System: How WELL HAS IT WORKED? Michele Fratianni
}

\section{Introduction}

The Treaty of Rome makes no reference to monetary union or specific exchange rate arrangements. In 1968 Raymond Barre, then commissioner of the European Community (EC), wrote a proposal advocating tighter consultations of member governments concerning macroeconomic policy and in particular monetary policy. The celebrated Werner Report of 1970 was an outgrowth of Barre's ideas. Although this report set monetary union as the ultimate EC objective, it was careful to emphasize (1) preconditions in the form of coordinated policies and (2) the establishment of narrower margins of fluctuations around exchange rate par values. The so-called snake arrangement, instituted in 1972, was believed to be the Werner Report in action. In fact, from the Werner Report the "snake" system borrows only the idea of reducing currency fluctuations without setting a machinery to coordinate policies. The "snake" failed.

The decision taken in 1978 by Chancellor Helmut Schmidt and President Giscard d'Estaing to create a "zone of monetary stability" came as a surprise, not only to the general public but also to central banks. Samuel Brittan (1979) speculated that the birth of the European Monetary System (EMS) had less to do with a desire for monetary stability than a Franco-German reaction to the weakness of the dollar and the unreliability of the Carter Administration. Whatever the reasons, the EMS became a reality on March 13, 1979.

Several authors predicted failure or at least modest success. Benjamin Cohen (1981, p. 21) stated that "the potential for an inflationary

Cato Journal, Vol. 8, No. 2 (Fall 1988). Copyright (C) Cato Institute. All rights reserved. The author is Professor of Business Economics and Public Policy at Indiana University. He gratefully acknowledges the comments by Juergen von Hagen and Alan Walters on earlier versions of the paper. 


\section{Cato Journal}

bias is there and, unlike the hypothethical reverse danger of a deflationary bias, could well become serious in practical terms. . . Any disciplinary effect of the joint float on a deficit member would probably be more than offset by the 'safety valve' of access to the credit facilities." In 1980, I predicted that "the EMS is destined to become an adjustable-peg system. How well this system will fare depends on the disparity of inflation rates and timeliness of parity adjustments. The current disparity of inflation rates and underlying policies among EEC countries suggests frequent realignments. Yet history teaches us that decisionmakers perceive parity changes as costly political decisions and, therefore, postpone taking action" (Fratianni 1980, p. 165). Roland Vaubel (1980) identified in the EMS the emergence of "egalitarianism, collectivism, and etatism" and worried about the built-in moral hazard incentives and inflation bias.

The EMS has not failed. Many economists and policymakers consider it a success, partly on the strength of the evidence I will review in this paper. Yet, the relevant question is not whether the EMS has survived or done well according to some absolute criterion, but whether it has performed better or worse than an alternative exchange rate regime. Needless to say, this is a demanding task because of the difficulty of holding other things constant.

In the remainder of the paper, I first compare the performance of the EMS countries both with the countries' own pre-EMS history and with non-EMS countries. Next, I consider the workings and merit of the EMS relative to the free-floating alternative. While there is a considerable amount of theoretical work on the relative desirability between an EMS-type and a free-floating arrangement (with and without credible monetary authorities), the empirical work bearing on this proposition is still in its infancy. In the concluding section, I offer speculations concerning the motives of each EMS country in being part of the present arrangement.

\section{The Record}

This section reviews the EMS record on exchange rate variability, inflation rates, money growth, interest rates, and economic growth.

\section{Exchange Rates}

There have been 11 parity changes or realignments during the life of the EMS; 7 occurred during the first four years and 4 in the subsequent four years (see Appendix Table 1). In the approximately 8-year period from March 1979 to January 12, 1987, the Italian lira 
experienced the largest parity depreciation, 45 percent, vis-à-vis the Deutsche mark; the Dutch guilder had the smallest depreciation, 4 percent (see Appendix Table 2). ${ }^{1}$

Did these parity changes evolve to take into consideration inflation differentials within the EMS countries? In Appendix Tables 3 and 4, I have shown cumulative bilateral inflation rate differences-over the period of 1979-86-measured by percentage changes of the wholesale price index and the consumer price index, respectively. Italy, again, has had the highest inflation differential in relation to Germany (64 and 84 percentage points, respectively); the Netherlands, the smallest ( 1 and 3 percentage points, respectively). A comparison of Appendix Table 2 with Appendix Tables 3 and 4 reveals that bilateral depreciations were positively associated with a higher domestic inflation rate. ${ }^{2}$ This positive association, however, was far from being complete and left room for real exchange rate changes (sec Appendix Table 5). In particular, the French franc, the Italian lira, and the Irish pound have had sizeable real appreciations vis-àvis the other EMS currencies. With respect to the Deutsche mark, the French franc has appreciated 8 percentage points, the Italian lira 38 percentage points, and the Irish pound 35 percentage points. ${ }^{3}$

One interpretation of the EMS is that monetary authorities of the participating countries do not understand the EMS to be a fixed exchange rate arrangement, but rather as one aimed at preventing high variability of exchange rates. If high variability implies that exchange rate movements have a large unexpected component, riskaverse individuals will move resources away from the riskier trade sector to the less risky nontraded sector (provided mean and variance of the exchange rate change are independent of each other). Hence high variability of exchange rates-despite the existence of future or forward markets-hampers the growth of trade.

\footnotetext{
${ }^{1}$ The parity realignment of 2.6 percent between the Irish pound and the French franc was the smallest absolute parity change.

${ }^{2}$ The co-movement between nominal exchange rate realignments and inflation rate differentials was tested by regressing the cross-section data of Appendix Table 2 (Exr) on the cross-section data of Appendix Tables 3 and 4 (wpi and cpi, respectively):

$\mathrm{Exr}=-5.59+.65^{*} \mathrm{wpi}$

$\mathrm{SEE}=10.3$

$t$ values $(2.45)(9.86)$

$\mathrm{Exr}=-6.8+.50^{*} \mathrm{cpi} \quad \mathrm{SEE}=9.6$

(3.17) (10.7)

where $\mathbf{E x r}=$ nominal exchange rate; $\mathrm{wpi}=$ wholesale price index; $\mathbf{c p i}=$ consumer price index.

${ }^{3}$ These were the real exchange rate changes based on the consumer price index.
} 
Horst Ungerer et al. (1986) give detailed evidence about exchange rate variability within the EMS countries, within the non-EMS countries, and between them. Here are the salient results of this study. First, intra-EMS exchange rate variability-both nominal and real-declined after the creation of the EMS. This decline is particularly so for bilateral exchange rates, which is evidence that corroborates the earlier study by Kenneth Rogoff (1985) who had, instead, concentrated on predictability. The evidence shows that the variance of the forecast error of the risk-neutral rational expectations model was lower during the first five years of the EMS than during the preceding five years. In contrast, non-EMS exchange rate variability went up after the creation of the EMS.

Much more subtle is the evidence concerning the interaction between EMS and non-EMS countries. On the basis of the IMF's multilateral exchange rate model, there is little evidence in Ungerer et al. to suggest that the pre-EMS period behaves different from the post-EMS period. ${ }^{4}$ As an alternative, I computed the standard deviation and the coefficient of variations of the annual percentage change of the effective exchange rate as defined by the OECD (see below for a description of the data). My computation was for the seven EMS countries; three European non-EMS countries (Austria, the United Kingdom, and Switzerland); and three non-European countries (Canada, Japan, and the United States). The results, presented in Appendix Table 6, indicate a sizeable increase in variability for two of the EMS countries (Belgium and the Netherlands) in contrast to the rather stable pattern in non-EMS countries. This fact implies that part of the gain in reduced exchange rate variability within the EMS countries came at the expense of a higher variability of exchange rates between EMS and non-EMS countries. ${ }^{5}$

Why has there been a significant decline in the growth rate of intraEMS trade after 1979 , in relation to both its own past and to nonEMS trade growth, despite the achieved lower (within the EMS) exchange rate variability? ${ }^{6}$ De Grauwe and Verfaille (1987) tackle

${ }^{4}$ See Tables 28 and 29 in Ungerer et al. (1986).

${ }^{5}$ In support of this point Ungerer et al. (1986, Table 22) show that the coefficient of variation of bilateral exchange rates, measured with respect to non-EMS countries' currencies, rises from 36.3 in the period $1974-78$ to 46.7 in the period 1979-85 for the average EMS countries, and from 39.6 to 42.8 for the average non-EMS countries.

${ }^{6}$ See DeGrauwe (1985) for a report on the relevant trade statistics. Denmark, Ireland, and the United Kingdom (the new members of the EEC) have experienced larger trade growth rates with the EEC countries than the old members. Their late entry into customs union may explain in part the difference in performance. There is the possibility, applicable only to the United Kingdom, that the EMS arrangement has, in fact, retarded trade growth within the EEC. 
this issue by testing a cross-sectional model of bilateral export flows. The determinants of the export flows were the growth of demand of the importing country, the growth of output supply of the exporting country, the exchange rate variability, the nature of the trade arrangement between the pairs of countries, and an indicator of protectionism. The latter determinant was quantified by cumulative percentage overvaluation of the currency of the importing country. Overvaluation is defined in terms of productivity-adjusted real exchange rate. The main findings are that the slowdown in the growth of output in the EMS and the slowdown in the integration process had a larger impact on intra-EMS trade growth than the beneficial effect of lower exchange rate variability. What remains to be explained, according to the authors, is "whether the EMS arrangement might have induced both low exchange rate variability and low growth of output."

\section{Inflation Rates and Money Growth}

Proponents of the EMS have pointed to the reduction in inflation rates in the EMS countries as a sign of the system's success. Statements of this kind need to be carefully scrutinized in two ways. First, is the inflation rate during the EMS period significantly lower than in the pre-EMS period? Meaningful statistical inferences cannot be made by simply comparing two periods. Naturally, these periods will differ by the number, size, and nature of the shocks, as well as by the exchange rate regime under consideration. Only under the heroic assumption of equivalent shocks can we attribute to the exchange rate regime the decline in the inflation rate. To relax in part the assumption of homogeneous shocks-and this is the second pointone can compare the performance of the EMS economies with economies that are "similar" to the EMS economies, except for the exchange rate regime. ${ }^{7}$

In Appendix Table 7, I have reported the average inflation ratesmeasured in terms of the consumption deflator-of the eight EMS countries, the EMS average, and the averages of the non-EMS countries for the pre-EMS period 1974-78 and the post-EMS period 1979-86. The data are annual and come from the diskettes of the OECD, Economic Outlook no. 41, June 1987. The aggregation over countries was made by multiplying the country's growth rate by the country's weight, which was based on GNP share calculated in 1982 prices

\footnotetext{
${ }^{7} A$ more meaningful exercise, which is beyond the task of this paper, would require analyzing the disinflation of the EMS countries relative to that of the non-EMS countries in terms of the relative costs of disinflation.
} 


\section{Cato Journal}

and exchange rates. ${ }^{8}$ In addition to the two sample averages, Appendix Table 7 shows the difference between the two periods and indicates whether this difference is significantly different from zero. ${ }^{9}$

The essential point emerging from the table is that the small, two percentage-point decline in the inflation rate in the EMS is not statistically significant, whereas the large declines in the other six countries are. These results may not do justice to the drastic disinflation that has taken place in the EMS countries in the several years, and indeed the outcome would drastically change if we ignored the first four years of the EMS. Belgium had an inflation rate of 1.4 percent in 1986 compared to an inflation rate of 7.1 percent in 1982. For the following countries the first percentage is for 1986 and the second for 1982: Denmark, 3.6 percent compared to 9.8 percent; France, 2.2 percent compared to 10.6 percent; Germany, -0.4 percent compared to 4.7 percent; Ireland, 3.7 percent compared to 14.7 percent; Italy, 6.0 percent compared to 15.7 percent; and the Netherlands, 0 percent compared to 5.1 percent.

Different considerations can be made with respect to the growth rate of the money stock, which slows down significantly in Belgium, Germany, Italy, and the Netherlands but rises in the other three European non-EMS countries (see Appendix Table 7). The incompleteness of money data for Denmark and France, however, prevents us from making statistically relevant comparisons between EMS and non-EMS aggregates. As an alternative to the money stock, I considered the growth rate of the monetary base, which has the advantage of closely reflecting the policy actions of the central banks. ${ }^{10}$ In Appendix Table 8, I report the sample averages of the annualized growth rate of the monetary base of each EMS country and the relative growth rates of each as defined by the difference of the country's growth rate and by the growth rate of the EMS aggregate, excluding the country in question.

\footnotetext{
${ }^{8}$ These weights are Belgium $=1.1$, Denmark $=0.7$, France $=7.0$, Germany $=8.5$, Ireland $=0.2$, Italy $=4.5$, Netherlands $=1.8$, Austria $=0.9$, United Kingdom $=6.3$, Switzerland $=1.2$, Canada $=3.9$, Japan $=14.0$, United States $=40.9$.

${ }^{9}$ The following $t$ statistic was employed:

$$
t=\left(x_{1}-x_{2}\right) /\left[\operatorname{std} l\left(1 / n_{1}+1 / n_{2}\right)^{1 / 2}\right]
$$

where $\left.s t d=\left[n_{1}^{*} v a r_{1}+n_{2}^{*} v a r_{2}\right) /\left(n_{1}+n_{2}-2\right)\right]^{1 / 2}, x_{1}=$ sample average of the pre-EMS period, $x_{2}=$ sample average of the EMS period, $v a r_{1}=$ variance of the pre-EMS period, $v a r_{2}=$ variance of the EMS period, $n_{1}=$ number of observations in the preEMS period, and $n_{2}=$ number of observations in the EMS period.

${ }^{10}$ These are quarterly data obtained from the International Financial Statistics (line 14) of the IMF.
} 
Italy and Ireland experienced significant (but at the relatively high 20 percent confidence level) declines in the growth of the monetary base; France, in contrast, had an increase in the relative growth. The interplay of these forces within the EMS left the EMS monetary base growth in the 1979-86 period virtually unchanged with respect to the pre-EMS period. ${ }^{11}$

\section{Interest Rates}

Integration of the financial markets implies that, in the absence of expected real exchange rate changes, real rates of interest cannot differ among countries. Rogoff (1985) shows that the difference between German and French and between German and Italian shortterm real interest rates increased during the EMS period. Furthermore, the conditional variance of these interest rates-based on two alternative ways to proxy the expected rate of inflation-rose as well in the post-EMS period. ${ }^{12}$ Giavazzi and Pagano (1985) present evidence that the spread between offshore and onshore interest rates widens and becomes more variable when an expectation of a parity realignment sets in. By tying the evidence produced by Giavazzi and Pagano with that of Rogoff, one arrives at the conclusion that the reduced variability of the exchange rates cannot be credited to coordinated monetary policy, but rather to the existence of capital controls that have effectively put a wedge between German interest rates, on the one hand, and French and Italian interest rates, on the other hand. Charles Goodhart (1986), on the strength of this evidence, argues against the entry of the United Kingdom in the EMS, because the crucial role of London as a major financial center requires freedom of capital movement. ${ }^{13}$ To put it differently, if the cost of joining the EMS is the application of exchange controls, the EMS is not worth it.

The evidence on interest rates cited above was based on data going up to 1984. What has happened more recently? The most important development is the exchange liberalization process that has taken place both in Italy and France. This liberalization forces the real interest rates in these countries to rise relative to those abroad. In Appendix Table 9, I have calculated the short-term real rate of interest using two alternative data sets: the annual data of the OECD, and

\footnotetext{
${ }^{11}$ There is a slowdown in the growth rate of the monetary base of the "rest of the world," but it is not statistically significant. We should note that the growth rate of the monetary base has large variances in all countries, a fact that explains why apparently large drops in the sample means are not statistically significant.

${ }^{12}$ See Appendix Table 5.

${ }^{13}$ Walters (1986) rejects the EMS on these grounds, as well as on political-economy considerations.
} 


\section{Cato JournaL}

the monthly three-month Treasury rates published by Harris Bank's Weekly Review. In both instances I have assumed that individuals were blessed with perfect foresight as to the next period's rate of inflation. While the two data sets yield different quantitative results, qualitatively they concur in pointing to a narrowing of the differentials.

The narrowing of the interest-rate differential is consistent with the hypothesis that countries like France and Italy have used the exchange rate as an exogenous variable and have adopted a policy of letting their domestic currencies appreciate in real terms vis-à-vis the Deutsche mark.

\section{Economic Growth and Unemployment}

How have the EMS countries performed on the real side of the economy? The evidence is very clear concerning unemployment, less so about output growth. Unemployment rates have increased substantially in the post-EMS period: In each of the EMS countries the increase is statistically significant at the 5 percent level (see Appendix Table 10). But this statement is also true for the other three European countries that are not part of the EMS, in contrast with the experience of the Canada-Japan-U.S. group. The unemployment story does not carry over, however, to the growth of real GNP where the slowdown is statistically significant for France, Ireland, and the Netherlands. We should note that the growth rates of output in the 197478 period were low to begin with, making the economic slowdown even more pronounced.

The nature and size of the real slowdown in Europe is very controversial and is the subject of ongoing research. One critical issue is whether the higher unemployment results from high real wage rates (classical explanation) or from inadequate spending (Keynesian explanation). We should note that unemployment in Europe is largely concentrated among the young and the unskilled, particularly in well-defined geographical areas. In a recent paper Jacques Dreze et al. (1987) argue that European unemployment exhibits both classical and Keynesian characteristics. These economists propose a series of supply-side measures aimed at reducing the high wedge between the private cost of labor (inclusive of taxes) and the social cost (i.e., net of tax). But they also propose that Germany, France, and the United Kingdom should generate additional government spending for future expansion of productive capacity, which is currently almost fully used. ${ }^{14}$

\footnotetext{
${ }^{14}$ The proposal entails higher public debt today and more taxes in the future. The higher public debt today serves to induce an intertemporal substitution of labor away from the future (when the economy will be at full employment) and toward the present (when resources are unemployed).
} 
From the perspective of this paper the above discussion highlights that the EMS is a monetary arrangement, not a fiscal one. Indeed there is evidence that fiscal policies among the EMS countries were more divergent after 1979 than before.

\section{An Interpretation of the EMS}

The EMS was created to achieve "a zone of monetary stability in Europe" that would eventually culminate into the establishment of a European Monetary Fund. Central banks have interpreted "a zone of monetary stability" to mean (1) lower variability of exchange rates, and (2) lower and converging inflation rates among EMS countries.

The EMS has been successful in reducing nominal and real exchange rate variability. Yet, intra-EMS trade growth has fallen. It is conceivable that trade growth would have fallen even more with more exchange rate variability. As to inflation, the facts are more ambiguous. The achieved reduction in the inflation rates turns out to be not as significant as the reduction in inflation rates among non-EMS countries when the entire post-EMS period is considered. If, instead, one isolates the 1982-86 period, the story becomes much more favorable for the EMS. Finally, there is some evidence that France and Italy have used the EMS as a disinflationary mechanism, by letting their currencies appreciate in real terms vis-à-vis the Deutsche mark and letting their real rates of interest rise relative to the real rates of interest prevailing in Germany.

Two questions immediately come to mind. Why would France and Italy accept the discipline of the EMS in preference to appropriate domestic disinflationary policies? Why would Germany be part of a scheme that makes it a potential importer of inflation? The rest of the paper is devoted to answering these two questions.

\section{The Reputation Hypothesis}

The key issue underlying the first of the two questions is whether or not membership in the EMS facilitates disinflation relative to an independent policy of disinflation. High-inflation countries may find it worthwhile to join an EMS-type arrangement because of the benefit derived by linking their currencies to that of a low-inflation country. These benefits stem from the reputation that the low-inflation country's central bank has earned in the market place.

A central bank with little or no reputation faces an inflation rate higher than would prevail if the central bank had committed itself to 


\section{Cato Journal}

a credible strategy of disinflation. ${ }^{15}$ This central bank can borrow reputation by committing its country's currency to a policy of real exchange rate appreciation with respect to the currency of a lowinflation credible central bank. The EMS can be interpreted as an arrangement of this type, with the relatively high-inflation countries of France and Italy borrowing reputation from low-inflation Germany.

Giavazzi and Pagano (1986) explore theoretically the advantage of high-inflation countries of tying their hands as far as monetary policy is concerned. The critical point for these economists is not whether the EMS is an effective disciplinary force, but whether the highinflation countries gain from the arrangement.

The gain of reputation is only one aspect of joining the EMS; highinflation countries also have to consider the losses in competitiveness implied by real exchange rate appreciations. The Giavazzi-Pagano model postulates that monetary authorities prefer more output to less output, value a positive rate of inflation because it creates revenues, but dislike inflation variability because of its adverse effects on output. The latter responds positively to real exchange rate depreciation and inflation "surprises."

Finally, the real exchange rate of the high-inflation countries appreciates between realignments, but returns to its initial value at the time of a realignment (i.e., changes in parities are set equal to cumulative inflation differentials). Under these conditions, the EMS is worth joining if the authorities do not seek to extract revenues from inflation, an intuitive outcome. Equally intuitive is the result that the payoff of joining the EMS is ambiguous if the authorities value the inflation tax. The final outcome depends on the relative strength of the seigniorage, the present value of output loss because of inflation variability, and the tightness of the EMS regime. Unfortunately, no empirical measures of the three forces are critical in the determination of EMS membership. Only through revealed preference can we deduce that the seigniorage incentives are small enough, relative to the gain in reputation, to have made it worthwhile for France and Italy to remain in the EMS so far.

\section{Benefits to the Supplier of Reputation}

Let us turn to the second question raised earlier: What does Germany gain by being in the EMS? Participation in the EMS poses a

\footnotetext{
${ }^{15}$ There is one branch of the literature on reputation that considers conditions under which policy shifts are credible (e.g., Barro and Gordon 1983), while another branch emphasizes that the central bank is free to follow discretionary policies and determine its level of credibility (e.g., Cukierman and Meltzer 1986). The latter view does not make it clear that the EMS enjoys a comparative advantage in generating reputation over an independent monetary policy of disinflation.
} 
complex problem to Germany. As a supplier of monetary credibility the Bundesbank receives no reward from the EMS. In fact, the workings of the EMS make it "natural" for Germany to import inflation from high-inflation countries. On the other hand, the EMS makes it possible for the Deutsche mark (DM) to have smaller real appreciations than would be true under free floating.

This competitive advantage may justify why the German government has been more favorable toward the EMS than the Bundesbank. The Bundesbank does not have exclusive authority to set priorities for the economy as a whole. In reality there are conflicts within branches of the executive. Germany, as represented by the Ministry of Finance, is more favorable to a DM real depreciation than Germany represented by the Bundesbank (see Tsoukalis 1987). By German law, the Ministry of Finance, not the Bundesbank, decides the exchange rate arrangement. Indeed, as I mentioned before, Chancellor Schmidt's original decision to join the EMS-against the opposition of the Bundesbank-might have had less to do with monetary unification than with searching for an expedient way to diffuse the brunt of heavy speculative flows into Germany (Brittan 1979).

The EMS may generate another benefit for Germany: the integration of financial markets in Europe and, hence, smaller German vulnerability to changes in foreign economic policy. It is not surprising that German authorities have consistently pushed for the integration of financial markets, with France and Italy relaxing exchange controls. The unfolding of tighter financial integration ought to raise the substitutability between DM-denominated assets and assets denominated in French francs and in liras. The benefit for Germany will be less vulnerability to changes in U.S. economic policies. ${ }^{16}$

\section{Evidence on Reputation}

Giavazzi and Giovannini (1987) address the issue of how important reputation has been in the EMS. They test for the empirical size of reputation by employing the famous Lucas (1979) critique to econometric practice in a positive manner. Since the institution of the EMS represents a new policy regime, it follows that any well-specified model of inflation estimated before the EMS will tend to overpredict inflation during the EMS period for countries borrowing reputation and to underpredict for reputation-supplying Germany. Giavazzi and Giovannini estimate vector-autoregressive models that act as "idealized" reduced-form equations for changes in the price level, nominal

${ }^{16}$ The asymmetries noted by Giavazzi and Pagano (1985) will have then disappeared. 
wages, and output. These variables are postulated to depend on their lagged values, money growth, changes in the relative price of imported raw materials, and changes in the relative price of imported finished goods, as well as on a smattering of country-specific dummy variables.

The authors find only one significant change in the overall values of the estimated coefficients before and after the establishment of the EMS; that change occurs for the French price inflation. As Giavazzi and Giovannini admit (p. 16), "This result might suggest that the EMS has not brought about any of the changes in expectations that we describe in the sections above, except for the price equation in France." Since the authors do not provide statistics about the relative forecast accuracy of the models before and after the EMS, the issue of the effectiveness of the regime change cannot be explored more deeply.

What we are left with are graphs of the actual and predicted values of the models in the post-EMS period. These graphs, in the absence of formal statistics, become the evidence upon which Giavazzi and Giovannini evaluate the reputation hypothesis. The graphs for Danish and German inflation "appear" to be consistent with the hypothesis. Besides importing inflation from the other EMS countries, Germany also seems to be a loser on the real side of the economy.

This conclusion runs counter to the popular notion that Germany is a deflationary force on the system.

Curiously enough, the United Kingdom appears to have been able to have its cake and eat it too with systematic negative forecast errors in the inflation rate and with positive forecast errors in output. This result at face value vindicates Mrs. Thatcher's insistence in not being part of the EMS; and it is consistent with Alan Walter's (1986) assessment of the EMS.

\section{Bundesbank Leadership}

There is virtual unanimity in the literature that, despite the intentions of the founding fathers to create a democratic institution, the EMS behaves as if Germany were a price leader.

France has been more than vociferous in denouncing the dominant role of Germany. In January 1987, France refused to intervene as the franc fell to the compulsory intervention floor; the Bundesbank had to intervene. Inspired by France, the finance ministers of the EC in September 1987 modified the rules governing interventions and their financing. ${ }^{17}$

\footnotetext{
${ }^{17}$ Masera (1987) outlines the principal institutional changes of the September 12-13, 1987, decision by the EC Council of Finance Ministers. In addition to the change
} 
The key change concerns the access of weak-currency countries to automatic credit through the Very Short-term Financing Facility. Mr. Balladur, the French finance minister, has interpreted the change as meaning "a presumption of automaticity" (an oxymoron?), whereas Mr. Poehl has interpreted the September decision as giving the Bundesbank the discretion to decide each case on its merit, the criterion being that "the main pre-condition will be that it does not threaten price stability in Germany" (The Economist 1987). It is too early to judge whether the institutional innovations pushed by France and backed by other countries will nudge the Bundesbank to alter its monetary policy. Much will depend on the Bundesbank's ability to sterilize interventions in the exchange markets.

\section{Conclusion}

The European Monetary System has not failed. The potential for an inflationary bias predicted by many economists has not materialized. So much is clear. Less clear is the matter of whether the EMS has been a success. The evidence marshalled in this paper indicates that the EMS has achieved lower exchange rate variability. Yet, intraEMS trade growth has declined. The reduction in inflation rates, greatly praised by proponents of the EMS, turns out to be modest when compared to the reduction achieved by other countries. The stronger evidence pertains to the willingness of high-inflation France and Italy to have used the EMS as a disinflationary mechanism. The real value of the franc and the lira has appreciated in relation to the mark, while the wedge between German real interest rates, on the one hand, and French and Italian real interest rates, on the other hand, has shrunk. The early reliance of France and Italy on exchange controls has given way to later efforts to open up their financial markets.

The preference of France and Italy to join the EMS over a domestically driven disinflation suggests that the Banque de France and Banca d'Italia are relatively weak institutions and lack the reputation of the Bundesbank. By committing themselves to a policy of real exchange rate appreciations, France and Italy use the reputation of the Bundesbank in lowering the inflation rate at a lesser cost than would be possible through an independent monetary policy.

discussed in the text, there is a time extension of the Very Short-term Financing Facility; a larger role given to the "official" ECU; and an engagement to monitor exchange rates, external imbalances, and monetary conditions in each of the EMS countries. The decision was written with unusually guarded language. 
German participation in the EMS is problematic. The Bundesbank supplies credibility to the system but gains virtually nothing. As we have shown, the impetus to join the EMS came from the German government, not from the Bundesbank. The government has supported the EMS because the arrangement has provided for smaller real appreciations of the Deutsche mark than under a regime of free floating. Germany also benefits from the integration of European financial markets, giving it a further justification for joining and remaining in the EMS.

Belgium, Luxembourg, the Netherlands, and Denmark are small countries that have embraced, to different degrees, a Deutsche mark standard. The United Kingdom has refused to join the EMS for fear of losing independence of monetary policy. The evidence reviewed in this paper does not indicate that the United Kingdom has lost by staying out. Ireland, a small country not linked to the Deutsche mark area, remains a puzzle as to its gain from EMS participation.

The EMS so far has run as a German-dominated system. While there are pressures to make the arrangement more democratic, it is too early to predict any fundamental changes. However, should democratization come about without an adequate amount of shared reputation, a great deal of the raison d'être of the EMS would have disappeared.

\section{Appendix Tables}

The following tables provide information on the performance of the EMS since its inception in 1979. Performance is viewed both within the EMS and relative to non-EMS countries. The data pertain to exchange rate variability, monetary growth and inflation, real interest rates, economic growth, and unemployment. 
APPENDIX TABLE 1

ExCHANGE Rate REALignMENTS Within The EMS

\begin{tabular}{|c|c|c|c|c|c|c|c|c|}
\hline & & $\mathrm{DM}$ & HFL & FF & BFR & LIT & DKR & IRL \\
\hline 24 Sept & 1979 & 2.0 & - & - & - & - & -2.9 & - \\
\hline 30 Nov. & 1979 & - & - & - & - & - & -4.8 & - \\
\hline 23 Mar. & 1981 & - & - & - & 一 & -6.0 & - & - \\
\hline 5 Oct. & 1981 & 5.5 & 5.5 & -3.0 & - & -3.0 & - & - \\
\hline 22 Feb. & 1982 & - & - & - & -8.5 & - & -3.0 & - \\
\hline 14 Jun. & 1982 & 4.25 & 4.25 & -5.75 & - & -2.75 & - & - \\
\hline 21 Mar. & 1983 & 5.5 & 3.5 & -2.5 & 1.5 & -2.5 & 2.5 & -3.5 \\
\hline 22 Jul. & 1985 & 2.0 & 2.0 & 2.0 & 2.0 & -6.0 & 2.0 & 2.0 \\
\hline 7 Apr. & 1986 & 3.0 & 3.0 & -3.0 & 1.0 & - & 1.0 & - \\
\hline 4 Aug. & 1986 & - & 一 & 一 & - & 一 & 一 & -8.0 \\
\hline 12 Jan. & 1987 & 3.0 & 3.0 & - & 2.0 & - & - & - \\
\hline
\end{tabular}

NoTE: The numbers are percentage changes of a given currency's bilateral central rate against those currencies whose bilateral parities were not realigned. A positive number denotes an appreciation, and a negative number denotes a depreciation. On March 21, 1983, and on July 22, 1986, all parities were realigned.

BFR-Belgium/Luxembourg franc, DKR-Danish kroner, DM-Deutsche mark, FF-French franc, LIT-Italian lira, IRISH £-Irish pound, HFLNetherlands guilder.

Source: Commission of the European Communities.

APPENDIX TABLE 2

Percentage Change in Bilateral

Parities from March 13, 1979, to January 12, 1987

\begin{tabular}{|c|c|c|c|c|c|c|c|}
\hline & BFR & DKR & DM & $\mathrm{FF}$ & LIT & IRISH $£$ & HFL \\
\hline BFR & & 2.94 & -27.18 & 10.13 & 18.30 & 7.48 & -23.29 \\
\hline DKR & & & -30.12 & 7.19 & 14.75 & 4.54 & -26.23 \\
\hline $\mathrm{DM}$ & & & & 37.31 & 45.48 & 34.16 & 3.89 \\
\hline FF & & & & & 8.18 & -2.64 & -34.81 \\
\hline LIT & & & & & & -10.82 & -41.59 \\
\hline IRISH $£$ & & & & & & & -30.77 \\
\hline
\end{tabular}

Note: A positive number denotes a devaluation, and a minus sign denotes an appreciation of the currency shown in the column heading with respect to the currency shown in the row heading.

Source: Ungener et al. (1986, Table 6) and San Paolo, ECU Newsletter, January 1987. 
APPENDIX TABLE 3

Cumulative Bilateral Inflation Differential

Measured by the Wholesale Price Index

OVER the Period 1979-1986

\begin{tabular}{|c|c|c|c|c|c|c|c|}
\hline & BFR & DKR & DM & FF & LIT & IRISH $£$ & HFL \\
\hline BFR & & 28.1 & -4.3 & 37.9 & 59.3 & 33.1 & -2.9 \\
\hline DKR & & & -32.4 & 9.8 & 31.2 & 5.0 & -31.0 \\
\hline $\mathrm{DM}$ & & & & 42.2 & 63.6 & 37.4 & 1.4 \\
\hline $\mathrm{FF}$ & & & & & 21.4 & -4.8 & -40.8 \\
\hline LIT & & & & & & -26.2 & -62.2 \\
\hline IRISH $£$ & & & & & & & -36.0 \\
\hline
\end{tabular}

NoTE: A positive (negative) number indicates that the inflation rate of the country shown in the column heading is cumulatively higher (lower) than that of the country shown in the row heading.

Source: International Monetary Fund, International Financial Statistics, Yearbook 1987.

APPENDIX TABLE 4

Cumulative Bilateral Inflation Differential Measured by the Consumer Price Index over the PERIOD 1979-86

\begin{tabular}{|c|c|c|c|c|c|c|c|}
\hline & $\mathrm{BFR}$ & DKR & $\mathrm{DM}$ & FF & LIT & IRISH $£$ & HFL \\
\hline BFR & & 17.7 & -18.8 & 27.0 & 65.0 & 69.6 & -15.8 \\
\hline DKR & & & -36.5 & 9.3 & 47.3 & 31.9 & -33.5 \\
\hline DM & & & & 45.8 & 83.8 & 68.8 & 3.0 \\
\hline $\mathrm{FF}$ & & & & & 38.0 & 22.6 & -42.8 \\
\hline LIT & & & & & & -15.4 & -80.8 \\
\hline IRISH $£$ & & & & & & & -65.4 \\
\hline
\end{tabular}

Note: A positive (negative) number indicates that the inflation rate of the country shown in the column heading is cumulatively higher (lower) than that of the country shown in the row heading.

Source: International Monetary Fund, International Financial Statistics, Yearbook 1987. 


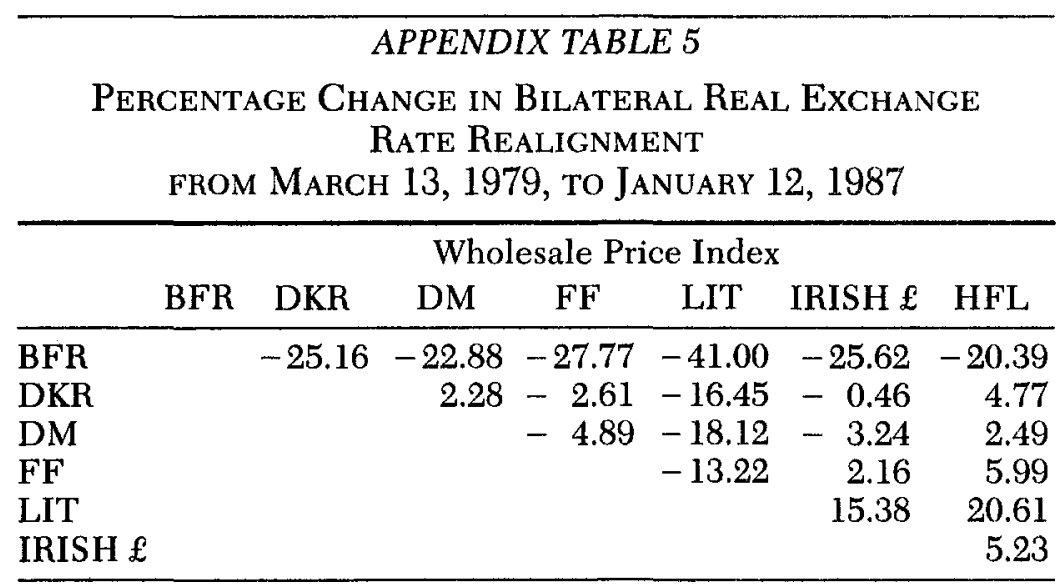

\begin{tabular}{|c|c|c|c|c|c|c|c|}
\hline & \multicolumn{7}{|c|}{ Consumer Price Index } \\
\hline & $\mathrm{BFR}$ & DKR & DM & FF & LIT & IRISH $£$ & HFL \\
\hline BFR & & -14.76 & -8.38 & -16.87 & -46.7 & -62.12 & -7.49 \\
\hline DKR & & & 6.38 & -2.11 & -32.55 & -27.36 & 7.27 \\
\hline DM & & & & -8.49 & -38.32 & -34.64 & 0.89 \\
\hline FF & & & & & -29.82 & -25.24 & 7.99 \\
\hline LIT & & & & & & 4.58 & 39.21 \\
\hline IRISH $£$ & & & & & & & 34.63 \\
\hline
\end{tabular}

NoTE: A positive number indicates a real depreciation of the country's currency shown in the column heading with respect to the country's currency shown in the row heading. The real exchange rate changes were obtained by subtracting the cumulative inflation differences of Appendix Table 3 and Appendix Table 4 from the cumulative nominal parity changes shown in Appendix Table 2. 
Variability of the Annual Growth of the Effective Exchange Rate

\begin{tabular}{|c|c|c|c|c|c|}
\hline \multirow[b]{2}{*}{ Countries } & \multicolumn{2}{|c|}{ Period 1974-78 } & \multicolumn{2}{|c|}{ Period 1979-86 } & \multirow[b]{2}{*}{ F Ratio ${ }^{a}$} \\
\hline & $\begin{array}{l}\text { Standard } \\
\text { Deviation }\end{array}$ & $\frac{\text { Standard Deviation }}{\text { Mean }}$ & $\begin{array}{l}\text { Standard } \\
\text { Deviation }\end{array}$ & $\frac{\text { Standard Deviation }}{\text { Mean }}$ & \\
\hline $\begin{array}{l}\text { Belgium } \\
\text { Denmark } \\
\text { France } \\
\text { Germany } \\
\text { Ireland } \\
\text { Italy } \\
\text { The Netherlands } \\
\text { Sum EMS }\end{array}$ & $\begin{array}{l}1.40 \\
1.61 \\
5.73 \\
2.15 \\
2.02 \\
4.31 \\
0.91 \\
1.55\end{array}$ & $\begin{array}{l}0.53 \\
3.36 \\
3.31 \\
0.45 \\
0.63 \\
0.44 \\
0.28 \\
5.33\end{array}$ & $\begin{array}{l}4.68 \\
3.68 \\
3.77 \\
3.32 \\
4.25 \\
3.03 \\
3.42 \\
2.72\end{array}$ & \begin{tabular}{r|}
3.78 \\
1.77 \\
2.04 \\
1.14 \\
1.81 \\
0.82 \\
1.81 \\
13.69
\end{tabular} & $\begin{array}{r}11.15 \\
5.19 \\
0.43 \\
2.38 \\
4.43 \\
0.50 \\
14.09 \\
3.07\end{array}$ \\
\hline $\begin{array}{l}\text { Austria } \\
\text { Switzerland } \\
\text { United Kingdom } \\
\text { Sum Euro Non-EMS }\end{array}$ & $\begin{array}{l}1.34 \\
6.50 \\
5.17 \\
4.11\end{array}$ & $\begin{array}{l}0.49 \\
0.61 \\
0.83 \\
1.44\end{array}$ & $\begin{array}{l}1.54 \\
3.14 \\
6.00 \\
4.18\end{array}$ & $\begin{array}{r}0.74 \\
1.07 \\
11.64 \\
16.27\end{array}$ & $\begin{array}{l}1.34 \\
0.23 \\
1.34 \\
1.04\end{array}$ \\
\hline $\begin{array}{l}\text { Canada } \\
\text { Japan } \\
\text { United States } \\
\text { Sum Non-Euro } \\
\text { Non-EMS }\end{array}$ & $\begin{array}{l}6.16 \\
9.83 \\
4.64 \\
2.41\end{array}$ & $\begin{array}{l}2.21 \\
1.88 \\
5.31 \\
5.34\end{array}$ & $\begin{array}{r}2.98 \\
10.51 \\
1.42 \\
4.81\end{array}$ & $\begin{array}{l}1.31 \\
2.18 \\
1.35 \\
2.77\end{array}$ & $\begin{array}{l}0.23 \\
1.14 \\
0.09 \\
3.99\end{array}$ \\
\hline
\end{tabular}

aF ratio is the ratio of the variance of the $1979-86$ period to the variance of the $1974-78$ period. The value of the $F(7,4)$ statistic at the 1 percent level $=14.98$; at 5 percent level $=6.09$.

Source: OECD, Economic Outlook no. 41, June 1987, data diskettes. 


\section{APPENDIX TABLE 7}

EMS vS. NON-EMS COUNTRIES:

A COMPARISON OF INFLATION AND MONEY GROWTH Rates

\begin{tabular}{|c|c|c|c|c|c|c|}
\hline \multirow[b]{2}{*}{ Countries } & \multicolumn{3}{|c|}{$\begin{array}{l}\text { Annual Percentage Change } \\
\text { Consumption Deflator }\end{array}$} & \multicolumn{3}{|c|}{$\begin{array}{l}\text { Annual Percentage Change } \\
\text { Money Stock }\end{array}$} \\
\hline & $1974-78$ & $1979-86$ & Difference & $1974-78$ & $1979-86$ & Difference \\
\hline$\overline{\text { Belgium }}$ & 8.54 & 5.53 & $-3.01 * *$ & 11.77 & 6.14 & $-5.63^{*}$ \\
\hline Luxembourg & 7.49 & 6.03 & -1.46 & - & - & - \\
\hline Denmark & 10.37 & 7.79 & -2.58 & - & 15.87 & \\
\hline France & 9.93 & 8.57 & -1.36 & - & 9.79 & \\
\hline Germany & 4.66 & 3.43 & -1.23 & 8.83 & 5.92 & $-2.91^{*}$ \\
\hline Ireland & 14.87 & 11.00 & -3.87 & 17.14 & 10.96 & -6.18 \\
\hline Italy & 16.12 & 13.17 & -2.95 & 19.05 & 12.89 & $-6.16^{*}$ \\
\hline The Netherlands & 7.65 & 3.75 & $-3.9 *$ & 12.07 & 7.05 & $-5.02 * *$ \\
\hline EMS Countries & 9.04 & 7.10 & -1.94 & - & - & - \\
\hline $\begin{array}{l}\text { European Non-EMS } \\
\text { Countries }^{\mathrm{a}}\end{array}$ & 12.40 & 7.15 & $-5.25^{*}$ & 4.91 & 11.63 & $6.72^{*}$ \\
\hline $\begin{array}{l}\text { Non-European } \\
\text { Countries }^{b}\end{array}$ & 8.04 & 5.24 & $-2.80^{* *}$ & 10.30 & 8.75 & $-1.55^{* *}$ \\
\hline
\end{tabular}

${ }^{a}$ Austria, United Kingdom, and Switzerland.

${ }^{b}$ Canada, Japan, and the United States.

* Statistically different from zero at the 5 percent significance level (t distribution, 11 degrees of freedom).

** Statistically different from zero at the 10 percent significance level ( $t$ distribution, 11 degrees of freedom).

Source: OECD, Economic Outlook no. 41, June 1987, data diskettes. 
APPENDIX TABLE 8

Growth of the Monetary Base in the EMS Countries (QuARTERLY DATA 1974:2-1986:4)

\begin{tabular}{|c|c|c|c|c|c|c|}
\hline \multirow[b]{2}{*}{ Countries } & \multicolumn{3}{|c|}{ Own Growth Rate } & \multicolumn{3}{|c|}{ Relative Growth Rate } \\
\hline & $1974-78$ & $1979-86$ & Difference & $1974-78$ & $1979-86$ & Difference \\
\hline Belgium & 6.00 & 2.40 & -3.60 & -1.38 & -5.3 & -3.92 \\
\hline Denmark & 11.58 & 12.37 & 0.79 & 4.39 & 5.06 & 0.67 \\
\hline France & 0.34 & 8.19 & 7.85 & -9.88 & 1.04 & $10.92 * * *$ \\
\hline Germany & 4.84 & 4.00 & -0.83 & -3.86 & -5.37 & -1.51 \\
\hline Ireland & 16.83 & 7.59 & $-9.24 * * *$ & 9.59 & 0.13 & $-9.46^{* * *}$ \\
\hline Italy & 21.46 & 13.97 & $-7.49 * * *$ & 17.44 & 8.03 & $-9.41^{*}$ \\
\hline The Netherlands & 8.88 & 5.78 & -3.10 & 1.69 & -1.82 & -3.51 \\
\hline Sum EMS & 7.32 & 7.46 & 0.14 & & & \\
\hline $\begin{array}{l}\text { Rest of the } \\
\text { World }\end{array}$ & 8.07 & 7.25 & -0.82 & & & \\
\hline
\end{tabular}

Note: The first three columns refer to the annual percentage change of the monetary base of the indicated country; the second three columns refer to the difference between the country's growth rate and that of the rest of the EMS. Rest of the world is defined as the weighted sum of Canada, Japan, the United Kingdom, and the United States.

*Statistically different from zero at the 5 percent significance level (t distribution, 49 degrees of freedom).

***Statistically different from zero at the 20 percent significance level (t distribution, 49 degrees of freedom).

SourCE: International Monetary Fund, International Financial Statistics, line 14, various issues. 
APPENDIX TABLE 9

EMS vs. NON-EMS COUNTRIES:

a Comparison of Real Interest Rates

\begin{tabular}{|c|c|c|c|c|c|c|}
\hline \multirow[b]{3}{*}{ Countries } & \multicolumn{4}{|c|}{ OECD Data } & \multirow[b]{3}{*}{ t Stat. } & \multirow[b]{3}{*}{ F Ratio ${ }^{b}$} \\
\hline & \multicolumn{2}{|c|}{$1974-78$} & \multicolumn{2}{|c|}{$1979-86$} & & \\
\hline & Mean & Std. & Mean & Std. & & \\
\hline Belgium & 1.31 & 2.03 & 6.11 & 1.35 & -4.61 & 0.44 \\
\hline France & -0.13 & 1.32 & 3.61 & 3.49 & -2.14 & 6.99 \\
\hline Germany & 1.33 & 1.27 & 4.27 & 1.91 & -2.80 & 2.26 \\
\hline Ireland & -4.00 & 2.99 & 3.17 & 4.51 & -2.90 & 2.28 \\
\hline Italy & -1.58 & 2.20 & 3.65 & 4.73 & -2.13 & 4.62 \\
\hline The Netherlands & -1.09 & 1.75 & 4.02 & 1.44 & -5.26 & 0.68 \\
\hline EMS Countries & 0.08 & 1.04 & 4.04 & 2.63 & -2.96 & 6.40 \\
\hline $\begin{array}{l}\text { European Non- } \\
\text { EMS Countries }\end{array}$ & -2.85 & 1.95 & 3.51 & 2.48 & -4.48 & 1.62 \\
\hline $\begin{array}{l}\text { Non-European } \\
\text { Countries }\end{array}$ & 0.10 & 0.28 & 2.45 & 1.12 & -4.23 & 16.00 \\
\hline
\end{tabular}


EMS vS. NON-EMS COUNTRIES:

A Comparison of Real Interest Rates

\begin{tabular}{|c|c|c|c|c|c|c|}
\hline \multirow[b]{3}{*}{ Countries } & \multicolumn{4}{|c|}{ Harris Bank Data } & \multirow[b]{3}{*}{ t Stat. $^{a}$} & \multirow[b]{3}{*}{ F Ratio ${ }^{\mathrm{b}}$} \\
\hline & \multicolumn{2}{|c|}{$1974-78$} & \multicolumn{2}{|c|}{$1979-86$} & & \\
\hline & Mean & Std. & Mean & Std. & & \\
\hline Belgium & 0.206 & 3.718 & 5.87 & 3.08 & -63.06 & 0.69 \\
\hline France & -1.26 & 2.07 & 4.18 & 4.25 & -57.43 & 4.22 \\
\hline Germany & 0.22 & 2.34 & 3.25 & 2.61 & -45.16 & 1.24 \\
\hline Ireland & N.A. & & & & & \\
\hline Italy & -4.49 & 7.94 & 1.51 & 5.44 & -34.11 & 0.47 \\
\hline The Netherlands & N.A. & & & & & \\
\hline UK & -4.91 & 6.25 & 3.18 & 5.78 & -50.54 & 0.86 \\
\hline Canada & -0.98 & 3.09 & 4.42 & 2.76 & -69.55 & 0.80 \\
\hline Japan & -2.65 & 5.41 & 2.84 & 3.87 & -44.99 & 0.51 \\
\hline USA & 1.70 & 2.20 & 3.44 & 86.12 & -0.98 & $1,532.37$ \\
\hline
\end{tabular}

at Statistic: The critical values with 11 degrees of freedom (OECD data) are 2.2 (5 percent) and 1.8 (10 percent); with 154 degrees of freedom (Harris Bank data) the values are 1.98 (5 percent) and 1.65 (10 percent).

'F Ratio: The critical values with (7,4) degrees of freedom (OECD data) are 14.98 (1 percent) and $6.09(5$ percent); with (92,62) degrees of freedom (Harris Bank data) the values are approximately 1.71 ( 1 percent) and 1.46 ( 5 percent).

SOURCE: OECD, Economic Outlook no. 41, June 1987, data diskettes; Harris Bank, Weekly Review, various issues. 


\begin{tabular}{|c|c|c|c|c|c|c|}
\hline \multicolumn{7}{|c|}{$\begin{array}{l}\text { EMS vS. NON-EMS COUNTRIES: } \\
\text { A COMPARISON OF OUTPUT GROWTH AND UNEMPLOYMENT RATES }\end{array}$} \\
\hline \multirow[b]{2}{*}{ Countries } & \multicolumn{3}{|c|}{$\begin{array}{l}\text { Annual Percentage Change } \\
\text { of Real GNP }\end{array}$} & \multicolumn{3}{|c|}{ Unemployment Rate } \\
\hline & $1974-78$ & $1979-86$ & Difference & $1974-78$ & $1979-86$ & Difference \\
\hline Belgium & 2.31 & 1.42 & -0.89 & 5.25 & 10.75 & $5.5 *$ \\
\hline Luxembourg & 1.18 & 2.28 & 1.1 & 0.37 & 1.24 & $0.87^{*}$ \\
\hline Denmark & 1.55 & 2.31 & 0.76 & 5.16 & 8.69 & $3.53^{*}$ \\
\hline France & 3.03 & 1.52 & $-1.51 * *$ & 4.42 & 8.41 & $3.99 *$ \\
\hline Germany & 2.00 & 1.74 & -0.26 & 3.54 & 6.30 & $2.76^{*}$ \\
\hline Ireland & 3.77 & 0.55 & $3.22 *$ & 7.72 & 12.56 & $4.84^{*}$ \\
\hline Italy & 2.12 & 1.99 & -0.13 & 6.38 & 9.14 & $2.76^{*}$ \\
\hline The Netherlands & 2.55 & 1.04 & $-1.51^{* * *}$ & 5.15 & 11.45 & $6.3 *$ \\
\hline EMS Countries & 2.38 & 1.66 & -0.72 & 4.62 & 8.18 & $3.56^{*}$ \\
\hline $\begin{array}{l}\text { European Non-EMS } \\
\text { Countries }^{\mathbf{a}}\end{array}$ & 0.99 & 1.70 & 0.71 & 3.46 & 7.76 & $4.3 *$ \\
\hline $\begin{array}{l}\text { Non-European } \\
\text { Countries }^{b}\end{array}$ & 2.81 & 2.54 & -0.27 & 5.76 & 6.57 & .81 \\
\hline
\end{tabular}

austria, the United Kingdom, and Switzerland.

${ }^{b}$ Canada, Japan, and the United States.

*Statistically different from zero at the 5 percent significance level (t distribution, 11 degrees of freedom).

**Statistically different from zero at the 10 percent significance level (t distribution, 11 degrees of freedom).

***Statistically different from zero at the 20 percent significance level ( $t$ distribution, 11 degrees of freedom).

SOURCE: OECD, Economic Outlook no. 41, June 1987, data diskettes. 


\section{Cato Journal}

\section{References}

Barro, Robert, and Gordon, David. "Rules, Discretion, and Reputation in a Model of Monetary Policy." Journal of Monetary Economics 12 (July 1983): 101-21.

Brittan, Samuel. "European Monetary System: A Compromise that Could Be Worse than Either Extreme." The World Economy 2 (1979): 1-30.

Cohen, Benjamin J. "The European Monetary System: An Outsider's View." Essays in International Finance no. 142. Princeton: International Finance Section, Princeton University, 1981.

Cukierman, Alex, and Meltzer, Allan H. "A Theory of Ambiguity, Credibility, and Inflation under Discretion and Asymmetric Information." Econometrica 5 (September 1986): 1099-128.

De Grauwe, Paul. "Memorandum." In Memoranda on the European Monetary System, House of Commons, Treasury and Civil Service Committee, the Financial and Economic Consequences of U.K. Membership of the European Communities, pp. 5-11. London, 1985.

De Grauwe, Paul, and Verfaille, Guy. "Exchange Rate Variability, Misalignment, and the European Monetary System." Katholieke Universiteit te Leuven, 1987.

Dreze, Jacques; Wypslosz, Charles; Bean, Charles; Giavazzi, Francesco; and Giersch, Herbert. "The Two-Handed Growth Strategy for Europe: Autonomy through Flexible Cooperation." Economic Papers, no. 60. Brussels: Commission of the European Communities, October 1987.

The Economist. "No Parity of Power in the EMS." 19 September 1987.

Fratianni, Michele. "The European Monetary System: A Return to an Adjustable-Peg Arrangement." In Monetary Institutions and the Policy Process, pp. 139-72. Edited by Karl Brunner and Allan H. Meltzer. CarnegieRochester Conference Series on Public Policy, vol. 13, 1980.

Giavazzi, Francesco, and Giovannini, Alberto. "The Role of the ExchangeRate Regime in a Disinflation: Empirical Evidence on the European Monetary System." Paper presented at the American Economic Association Meetings, Chicago, 28-30 December 1987.

Giavazzi, Francesco, and Pagano, Marco. "Capital Controls and the European Monetary System." In Capital Controls and Foreign Exchange Legislation. Euromobiliare, Occasional Paper, June 1985.

Giavazzi, Francesco, and Pagano, Marco. "The Advantage of Tying One's Hands: EMS Discipline and Central Bank Credibility." Center for Economic Policy Research Discussion Paper no. 135. London, October 1986.

Goodhart, Charles. "Has the Time Come for the U.K. to Join the EMS?" The Banker, February 1986.

Harris Bank. International money market and foreign exchange rates, Weekly Review. Chicago, various issues.

International Monetary Fund. International Financial Statistics. Washington, D.C., various issues.

Lucas, Robert E. "Econometric Policy Evaluation: A Critique." In The Phillips Curve and Labor Markets, pp. 19-46. Edited by Karl Brunner and Allan H. Meltzer. Carnegie-Rochester Conference Series on Public Policy, vol. $1,1976$. 


\section{EUROPEAN MONETARY SYSTEM}

Masera, Rainer. L'unificazione monetaria europea. Bologna: il Mulino, 1987.

Organization for Economic Cooperation and Development. Economic Outlook no. 41, Paris, June 1987, data diskettes.

Rogoff, Kenneth. "Can Exchange Rate Predictability Be Achieved without Monetary Convergence?" European Economic Review 28 (June-July 1985): 93-115.

San Paolo. ECU Newsletter. Torino, January 1987.

Tsoukalis, Loukas, "The Political Economy of the European Monetary System." Paper presented at the conference on the Political Economy of International Macroeconomic Policy Coordination, Andover, Mass., 5-7 November 1987.

Ungerer, Horst; Evans, Owens; Mayer, Thomas; and Young, Philip. The European Monetary System: Recent Developments. Washington, D.C.: International Monetary Fund, December 1986.

Vaubel, Roland. "The Return to the New European Monetary System: Objectives, Incentives, Perspectives." In Monetary Institutions and the Policy Process, pp. 173-221. Edited by Karl Brunner and Allan H. Meltzer. Carnegie-Rochester Conference Series on Public Policy, vol. 13, 1980.

Walters, Alan. Britain's Economic Renaissance: Margaret Thatcher's Reforms 1979-1984. New York: Oxford University Press, 1986. 


\section{A Critical View of the EMS Alan Walters}

With the exception of one or two reservations, I find myself in substantial agreement with Michele Fratianni's paper. My main concern is that it did not provide a sharp and concise description of this reptilian descendant of the deceased snake. Let us try to fill this gap.

\section{A Caricature of the EMS}

Clearly, the purpose of the European Monetary System (EMS) was to provide intermember exchange rate stability until the occasion of realignment. Let us therefore suppose that realignments take place at the end of the year, and that the EMS currencies have fixed exchange rates for that year. Let us also assume that there are no capital controls and no regulations inhibiting or taxing foreign acquisition of financial assets. Then the fixed exchange rates will necessarily imply that nominal interest rates, for periods of maturity less than one year, will be equal. Arbitrage will ensure such equality.

To suffuse an air of verisimilitude, let us suppose the two countries, Italy and Germany, are locked into this EMS-induced equality of interest rates. This equality will occur whatever the ambient rates of inflation in the two countries. Let us therefore suppose that the ambient rate of inflation in Italy is 10 percent and that Germany has stable prices. The common nominal interest rate, we may assume, is 5 percent.

This implies that the real interest rate in Germany is positive at 5 percent, whereas in Italy there is a negative real interest rate of 5 percent. Such interest rates are, of course, precisely the opposite of those that are required for reducing the rate of inflation in Italy and for promoting growth in Germany. With the short interest rate as the most important instrument of monetary control, the low real interest

CatoJournal, Vol. 8, No. 2(Fall 1988). Copyright (C) Cato Institute. All rights reserved.

The author is Professor of Economics at Johns Hopkins University and a Senior Fellow at the American Enterprise Institute. 


\section{Cato Journal}

rates in Italy would stimulate a rapid expansion of lira, whereas the high real rates in Germany would depress the demand for marks. Thus it appears that the EMS would induce monetary incentives that are exactly the opposite of those required for "harmonization" of inflation rates.

One may concede this point but argue that the domestic pressures on interest rates would surely give rise to a narrowing of the real interest rate gap. (One would also need to concede that there are costs of capital crossing frontiers to violate the one-price result of perfect arbitrage.) Let us imagine therefore that nominal rates are 3 percent in Germany and 7 percent in Italy. Although the real rates are plus 3 percent in Germany and minus 3 percent in Italy, there is still an incentive for owners of mark deposits to overcome the costs of capital crossing the Italian frontier since deposits in lira earn 7 percent, which can be converted at the end of the year to marks at the fixed exchange rate. Thus the pressure is for capital to move from Germany to Italy. This is the reverse of an equilibriating flow of reserves. Again it will enhance the disparity in inflation rates. (One of the effects of the automaticity, which was recently negotiated, is to make sure official capital flows quickly offset the private flows.)

With monetary policy so emasculated, the main weight of adjustment must be taken over by fiscal policy that is aided and abetted by direct controls over wages and prices. To contain and reduce the inflation in Italy, tight fiscal policies would cause unemployment to rise. Again one would expect disparate fiscal policies-and Fratianni has observed evidence of this during 1979-87.

This pure fixed exchange rate system is, of course, a caricature of the EMS. In particular, there is considerable room ( 2.25 percent and, for Italy, 6 percent) within which the exchange rates can move from the central parity. Furthermore, the realignments of new parities can come at unexpected times. All these considerations blur the perversity we outlined in the pure caricature. But, at the same time, they destroy the one advantage of the EMS: namely, the fixity of exchange rates in the short run.

Fratianni says that the members of the EMS now regard it not as a short-run stabilizer, but as a mechanism aimed at "preventing high variability of exchange rates." But, as he points out, the reduction in variability within the EMS was eroded by a higher variability between the EMS and non-EMS countries. There is little enough stability to credit to the EMS account.

\section{Speculation, Capital Movements, and Reputation}

One of the frequent claims is that the EMS reduces speculation against currencies. It is, of course, very difficult to know precisely 
what this claim means. But surely the EMS process of realignmentsas in the devaluations of the franc and lira and the revaluation of the mark-provides the most risk-free speculation for any asset owner. Everyone knows the approximate date and direction of the change. It is not surprising that overnight interest rates of the franc shoot skyhigh as investors borrow to bet on such a sure thing. I suspect that the opportunity to join periodically in such a sure thing against sterling may explain some of the enthusiasm in the City of London for Britain joining the exchange rate mechanism.

The pressure of capital movements in the EMS and the difficulty of maintaining exchange rates encourage resorting to other methods for reducing the pressure. Both Italy and France have maintained capital controls and exercise considerable restrictions over domestic credit markets. Attempts to abolish capital controls and to deregulate domestic capital markets have yet to be realized. One suspects also that the increased trade barriers in Europe, compared with the sharp decreases in the 1970s, have been in part due to the pressures of the EMS.

On the issue of reputation and discipline, Fratianni nicely confirms my own conjectures. ${ }^{1}$ Before 1979 , the main European nation outside the EMS, the United Kingdom, grew at half the rate of Germany and France, but since the recession of 1982 , it has grown at twice the rate of Germany and France. British unemployment has been falling dramatically for three years, whereas in Germany, France, and Italy it is still increasing. The reduction in inflation has been quite as impressive as in those countries in the EMS. But I would attribute this British renaissance not entirely to its freedom from EMS entanglements, as in the study of Giavazzi and Giovannini, but primarily to Mrs. Thatcher. I refuse to regard Mrs. Thatcher as simply a realization of a random variable. She is neither random nor variable.

\section{Politicization of Exchange Rates}

Compared with a floating system, the EMS entails a considerable politicization of exchange rates. The occasion for realignments involves a great political bargaining session rather than an occasion on which to review the fundamentals of real exchange rates. The French denouncing the dominant role of Germany and the attempts to make the Bundesbank pursue more inflationary policies seem to point to a political Achilles' heel. Any departure from German hegemony would, as Fratianni hints, make a nonsense of what little rationale there is for the EMS.

'See Walters (1986, chap. 7). 


\section{Cato Journal}

\section{The Currency Board Alternative}

If the ultimate objective is the monetary integration of Europe through a European Central Bank (ECB) in a single currency area, then the EMS seems to be hardly a step in the right direction. It creates too many tensions, both economic and political. On the other hand, it is possible to develop sensible institutional arrangements that would usher in the integrated monetary system. One such institution, with massive historical precedent, is the currency board arrangement. Using the Bundesbank as the de facto ECB, member nations would hold 100 percent mark reserves against their own currency issues and would, at all times, exchange their currency against marks at a fixed rate. Such a fixed-rate system would provide automatic adjustments of the money supply to support the fixed rates. But, as everyone would agree, such integration is far beyond the bounds of the politically possible.

I can agree with Fratianni that the EMS "has not failed," but only in the sense that it has not broken down in mutual acrimony. In every other sense, which he examines so patiently, I would regard the EMS as a failure.

\section{Reference}

Walters, Alan. Britain's Economic Renaissance. New York: Oxford University Press, 1986. 